\title{
Różne oblicza zespołu Brugadów
}

\author{
Different faces of Brugada syndrome
}

\author{
Aleksandra Gąsecka, Dariusz Rodkiewicz \\ I Katedra i Klinika Kardiologii Warszawskiego Uniwersytetu Medycznego
}

\section{Streszczenie}

Zaprezentowano przypadek kliniczny 57-letniego pacjenta z zespołem Brugadów (BS), u którego elektrokardiograficzne cechy BS typu 2 ujawniły się pod wpływem gorączki w przebiegu infekcji dróg oddechowych. Pod wpływem flekainidu indukowano charakterystyczne dla BS zmiany odcinka ST typu 1. Ze względu na brak objawów klinicznych i brak spontanicznych zmian odcinka ST typu 1 pacjentowi nie implantowano kardiowertera-defibrylatora.

Słowa kluczowe: zespół Brugadów, nagły zgon sercowy, flekainid

Folia Cardiologica 2015; 10, supl. C: 7-9

\section{Wstęp}

Zespół Brugadów (BS, Brugada syndrome) jest dziedziczoną autosomalnie dominująco kanałopatią, w przebiegu której dochodzi do występowania groźnych dla życia zaburzeń rytmu serca, takich jak częstoskurcz komorowy, trzepotanie i migotanie komór. Większość przypadków jest spowodowanych mutacją w genie SCN5A kodującym kanał sodowy [1]. Zgodnie z wytycznymi Europejskiego Towarzystwa Kardiologicznego (ESC, European Society of Cardiology) wyróżnia się trzy typy zmian odcinka ST w BS (ryc. 1) [1].

\section{Opis przypadku}

Mężczyzna w wieku 56 lat z wywiadem astmy oskrzelowej, dotychczas nieleczący się z przyczyn kardiologicznych, zgłosił się do lekarza podstawowej opieki zdrowotnej (POZ) z powodu bólu gardła i gorączki, a następnie na podstawie zapisu elektrokardiograficznego (EKG) został skierowany na oddział kardiologii z podejrzeniem ostrego zespołu wieńcowego. Przy przyjęciu pacjent był w dość dobrym stanie ogólnym, bez bólu w klatce piersiowej i jawnych cech niewydolności serca. W EKG (ryc. 2) ob-

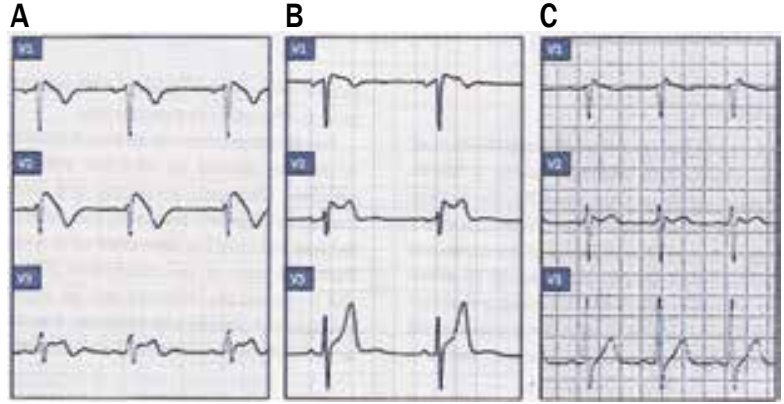

Rycina 1A-C. Zmiany odcinka ST w odprowadzeniach V1-V3 charakterystyczne dla zespołu Brugadów: A. Typ 1 - uniesienie punktu J $0 \geq 2 \mathrm{~mm}$ z zatoczkowym uniesieniem $\mathrm{ST} \geq 1 \mathrm{~mm}$ przechodzącym w ujemny załamek T; B. Typ $2-$ uniesienie punktu J $0 \geq 2 \mathrm{~mm}$ $z$ siodełkowatym uniesieniem $S T \geq 1 \mathrm{~mm}$, płaski lub dwufazowy załamek T; C. Typ 3- uniesienie punktu J o $\geq 2 \mathrm{~mm}$ z uniesieniem $\mathrm{ST}<1 \mathrm{~mm}$ (na podstawie [1])

serwowano uniesienie odcinka ST o morfologii BS typu 2 (siodełkowate uniesienie odcinka ST maksymalnie do $6 \mathrm{~mm}$ z płaskimi/dwufazowymi załamkami T w odprowadzeniach V2-V4). W badaniach dodatkowych stwierdzono 2-krotnie ujemne markery martwicy mięśnia sercowego. 


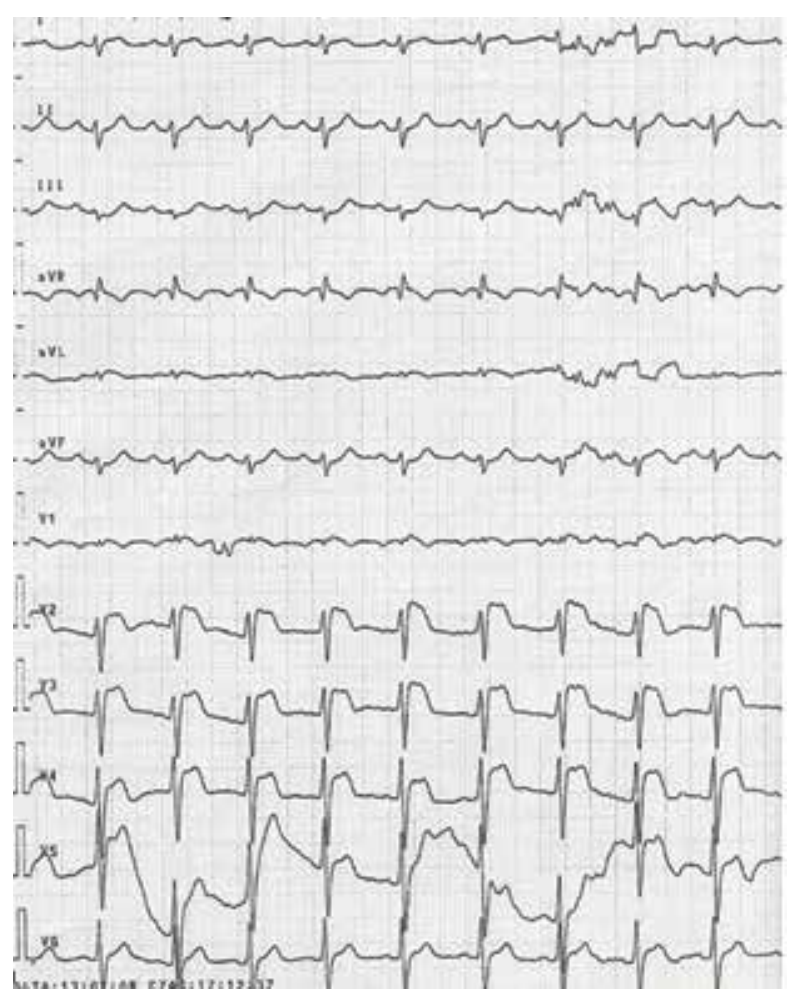

Rycina 2. Zapis elektrokardiograficzny chorego - cechy zespołu Brugadów typu 2

W badaniu echokardiograficznym nie zobrazowano zaburzeń kurczliwości. Ze względu na współistniejącą infekcję włączono antybiotykoterapię, uzyskując ustąpienie zmian elektrokardiograficznych po normalizacji temperatury ciała. W celu potwierdzenia diagnozy BS wykonano test z zastosowaniem flekainidu, uzyskując zapis EKG wskazujący na BS typu 1 (ryc. 3).Wykonano także badanie elektrofizjologiczne (EPS, electrophysiologic study), podczas którego wyzwolono nieutrwalony częstoskurcz komorowy. Ze względu na całokształt obrazu klinicznego pacjentowi nie implantowano kardiowertera-defibrylatora (pacjent bez objawów klinicznych, bez spontanicznych zmian odcinka ST typu 1, z dodatnim wynikiem EPS - wskazanie klasy IIb). Pacjenta wypisano z zaleceniami unikania leków niebezpiecznych dla pacjentów z BS (www.brugadadrugs. org), obniżania temperatury ciała w przypadku gorączki oraz unikania spożywania alkoholu (wskazanie klasy I).

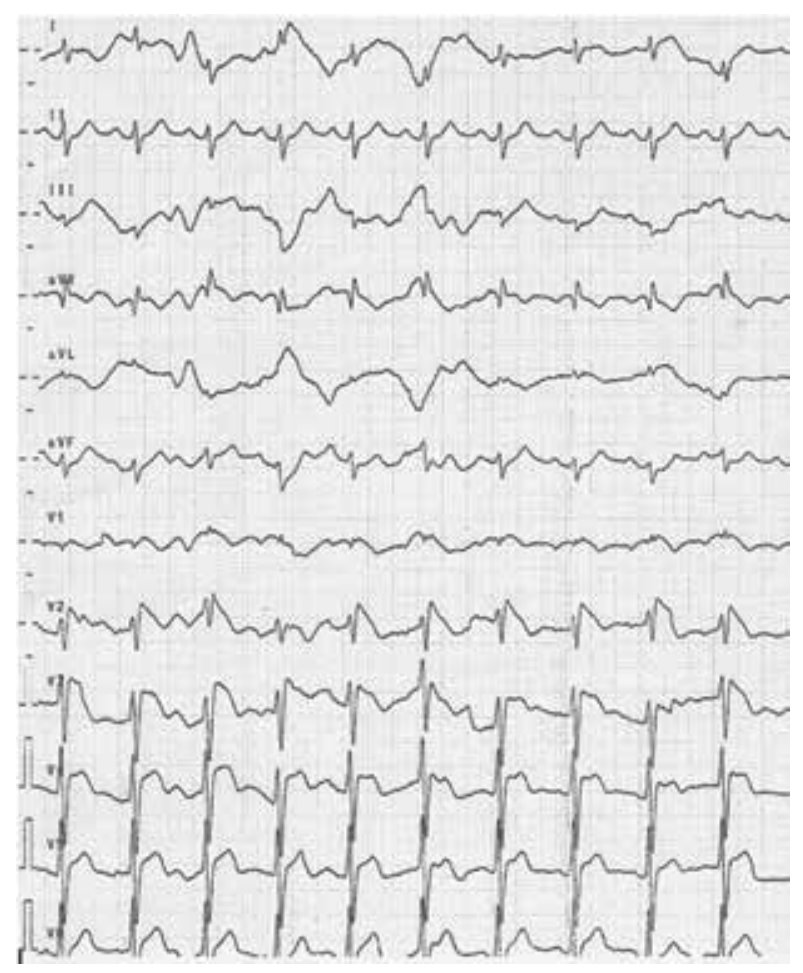

Rycina 3. Zapis elektrokardiograficzny chorego, dodatni test z zastosowaniem flekainidu - cechy zespołu Brugadów typu 1

Przeprowadzono również badania w kierunku BS u synów pacjenta, u których nie stwierdzono choroby.

\section{Podsumowanie}

Prezentowany przypadek kliniczny ukazuje różnorodność obrazu EKG w BS. Zmiany w odprowadzeniach innych niż V1-V3 występują u około 11\% pacjentów i utrudniają diagnostykę różnicową [2], prowadząc w wielu przypadkach do zbędnej w tej sytuacji klinicznej koronarografii [3]. Wnikliwa analiza EKG pozwoliła na postawienie właściwej diagnozy, a także umożliwiła wykluczenie choroby u synów pacjenta [4].

\section{Konflikt interesów}

Autorzy deklarują brak konfliktu interesów. 


\section{Abstract}

We present a clinical case of a 57-year-old patient with Brugada syndrome (BS), who presented with electrocardiographical features of BS type 2 in course of fever due to respiratory tract infection. Upon administration of flecainide ST segment elevation of type 1 was induced. As the patient had no clinical symptoms and no spontaneous abnormalities of ST segment, he did not receive an implantable cardioverter-defibrillator.

Key words: Brugada syndrome, sudden cardiac death, flecainid

Folia Cardiologica 2015; 10, supl. C: 7-9

\section{Piśmiennictwo}

1. Benito B., Brugada R., Brugada J., Brugada P. Brugada syndrome. Prog. Cardiovasc. Dis. 2008; 51: 1-22.

2. Sarkozy A., Chierchia G.B., Paparella G. i wsp. Inferior and lateral electrocardiographic repolarization abnormalities in Brugada syndrome. Circ. Arrhythm. Electrophysiol. 2009; 2: 154-161.
3. Deshpande A., Birnbaum Y. ST-segment elevation: Distinguishing ST elevation myocardial infarction from ST elevation secondary to nonischemic etiologies. World J. Cardiol. 2014; 6: 1067-1079.

4. Priori S.G., Wilde A.A., Horie M. i wsp. Executive summary: HRS/EHRA/ /APHRS expert consensus statement on the diagnosis and management of patients with inherited primary arrhythmia syndromes. Heart Rhythm 2013; 10: 85-108. 